\title{
MINERAL WATER MINING: QUALITY FOR HUMAN CONSUMPTION AND HEALTH PROMOTION
}

\section{ORIGINAL ARTICLE}

NUNES, Antônio José Ribeiro ${ }^{1}$

NUNES, Antônio José Ribeiro. Mineral water mining: quality for human consumption and health promotion. Revista Científica Multidisciplinar Núcleo do Conhecimento. Year. 06, Ed. 12, Vol. 12, pp. 41-60. December 2021. ISSN: 24480959, Access Link: https://www.nucleodoconhecimento.com.br/health/humanconsumption, DOI: 10.32749/nucleodoconhecimento.com.br/health/humanconsumption

\section{ABSTRACT}

This study demonstrates the aspects of research and mining in groundwater mining. It was intended to demonstrate the guidelines of the Mining Code and Water Code as legal beacons under the management of the National Mining Agency - ANM, federal regulator of mineral water exploration; to analyze the importance of water quality control for human consumption, from the compliance with Anvisa Resolutions - RDC$274 / 275 / 2005$, which standardize the vase and microbiological characteristics. The process to make groundwater available as a mineral good to be industrialized, goes through research stages, till the final test with laboratory analyses for water classification. In this context, its main question is: what is the importance of mineral water quality for human consumption in health promotion? And it aims to analyze the quality control of mineral water, its importance for human consumption and health promotion, as well as the benefits of it. For this, a bibliographic research was carried out, consultation with the relevant legislations, books and websites of public agencies. The results showed that mineral water mining is an activity present in the daily life of

\footnotetext{
${ }^{1}$ Post Graduated in Audit, Management and Environmental Expertise, Post Graduated in Occupational Safety Engineering, Specialist in Mineral Resources - Mining Engineer.
} 
society and its regular consumption contributes to the quality and promotion of healthy living, through control of the exploitation of mineral water mines, under the management of the National Mining Agency - ANM. It was evidenced that mineral water brings important health benefits: in body thermoregulation, heat absorption, nutrient transport, oxygen, hormones, composition of blood plasma, digestive juice, saliva formation, tears and urine. Being composed of different levels of micronutrients, which help alleviating health problems, such as: weakening of bones and muscles, reduction of collagen, dryness of the skin, low revitalization of cells and mucosa, aggravated by low consumption of water with drug properties and product of secular use that affect health. It was concluded that the prevalence of each type of mineral water and its composition, from ferruginous, sulfurous, radioactive, magnesian and iodized, can help in therapeutic treatments.

Keywords: Mining, Mineral Waters, Human Consumption, Mining Code.

\section{INTRODUCTION}

We can say that mineral waters are particular cases of groundwater, since this is their common origin, having a direct relationship with the hydrological cycle. By penetrating the interior of the subsoil in both rocky and/or soil environments, through which it passes, through the time of percolation, and depending on the depth, the waters are enriched in some constituents, determining their chemical and physicochemical composition, which give them characteristics (CPRM, 2021).

According to Feitosa (2008), the hydrological cycle represents the water path from the atmosphere through the phases of precipitation, infiltration, underground runoff, surface runoff, evaporation and evapotranspiration. The cycle starts from the condensation of water vapor in the atmosphere forming clouds that fall like rain. In the soil, part of the precipitated volume is intercepted by the plants, while another part infiltrates into the subsurface, promoting soil rehydration and recharge of the groundwater reserves. The non-infiltrated excess generates the surface runoff that feeds the streams, rivers and lakes. 
Serra (2009, p. 44) assesses that:

A composição química das rochas, por onde se infiltram as águas subterrâneas, é responsável por sua mineralização. As águas das chuvas penetram no solo e atravessam diversas camadas de rochas até estacionarem. Nesse trajeto por baixo do solo, a água passa por rochas com substâncias minerais, como o carbonato e o sulfato de cálcio, que se diluem na água, enriquecendo-a e adquirindo, assim, propriedades medicinais. Outros fatores importantes são a temperatura e a pressão, que ajudam a determinar características próprias à água. As águas minerais dividem-se em fracas, médias e fortes.

Mineral water can arise under the surface in specific locations, in springs or natural sources, underground environments of mines where prospecting is required for the discovery of stationary mineral waters or artificial sources from which they are captured. Mineral water has a differentiated chemical composition from common waters, since it is formed by chemical elements that determine the characteristic of drug action (SERRA, 2009).

Gorini (2000), analyzes that there are two theories that seek to explain the origin of mineral waters, which present controversies: the first, of meteoric origin, where scholars consider the origin from infiltration of rainwater in places of great depth; the second theory considers that mineral waters are of magmatic origin, where part of the mineral waters are the result of phenomena such as volcanism.

Water is regulated by Brazilian states, especially those of underground origin, which in order to be captured require a grant instrument, according to the relevant state legislation. Mineral water is classified as ore and is submitted to the National Mining Agency - ANM[2], therefore, it is under the rules of the Mineral Water Code.

The present study aims to evaluate the research and mining in mineral water mining, in compliance with the Mining Code and Water Code, in the control of exploration of mineral water mines; to analyze the importance of mineral water quality control for health promotion, in accordance with Anvisa Resolutions - RDC 274/2005 and RDC 275/2005. 
In this context, it has as a guide question: What is the importance of mineral water quality for human consumption and health promotion?

To answer this question, we chose to conduct a bibliographical research on the subject, with the purpose of contributing information and hypotheses.

The choice of the theme is justified based on the assumption that the Mineral Waters Code, Decree-Law No. 7,841/1945, Decree-Law No. 9,406/,2018, which regulated Decree-Law No. 227/1967 and ANVISA Technical Regulations - RDC 274/2005, for filler and RDC 275/2005, for microbiological characteristics, brought regulations in the management of the commercial use of mineral water sources that can be sent to a single and exclusive context, in the case of mineral waters with quality assurance for human consumption and health promotion.

The social and academic relevance of the study and groundwater protection measures and the improvement of the framework of mining areas representing the conditions of access to quality mineral water for the promotion of the population's health.

\section{THE NATIONAL WATER RESOURCES POLICY, WATER MANAGEMENT AND THE MINING CODE}

For several decades the commercialization of mineral water has been a reference, from bottled water, whose market has been expressly growing in the last three decades. Thus, the use of industrialized waters has important significance in the context of society, considering that the advances in communication have provided greater interaction of people, who every day have shown greater interest in the acquisition of healthier foods and among them, is industrialized mineral water, by the affordable availability and food security that the product presents, considering technological advances in the operationality of processes, increasingly automated and compliance with current standards.

According to Pitaluga (2006), mineral water was the product that in the last thirty years has had an exponential growth in consumption among Brazilians, positioning Brazil as 
among the 10 largest countries that consumers of mineral water in the world. According to the Brazilian Association of Soft Drink and Non-Alcoholic Beverage Industries $A B I R$, the per capita consumption of the Brazilian mineral water market, evaluated in 2020 , was $59.65 \%$, with a growth of $3.9 \%$ compared to 2019 .

Figure 1: Brazilian per capita consumption of mineral waters between 2010 and 2019.

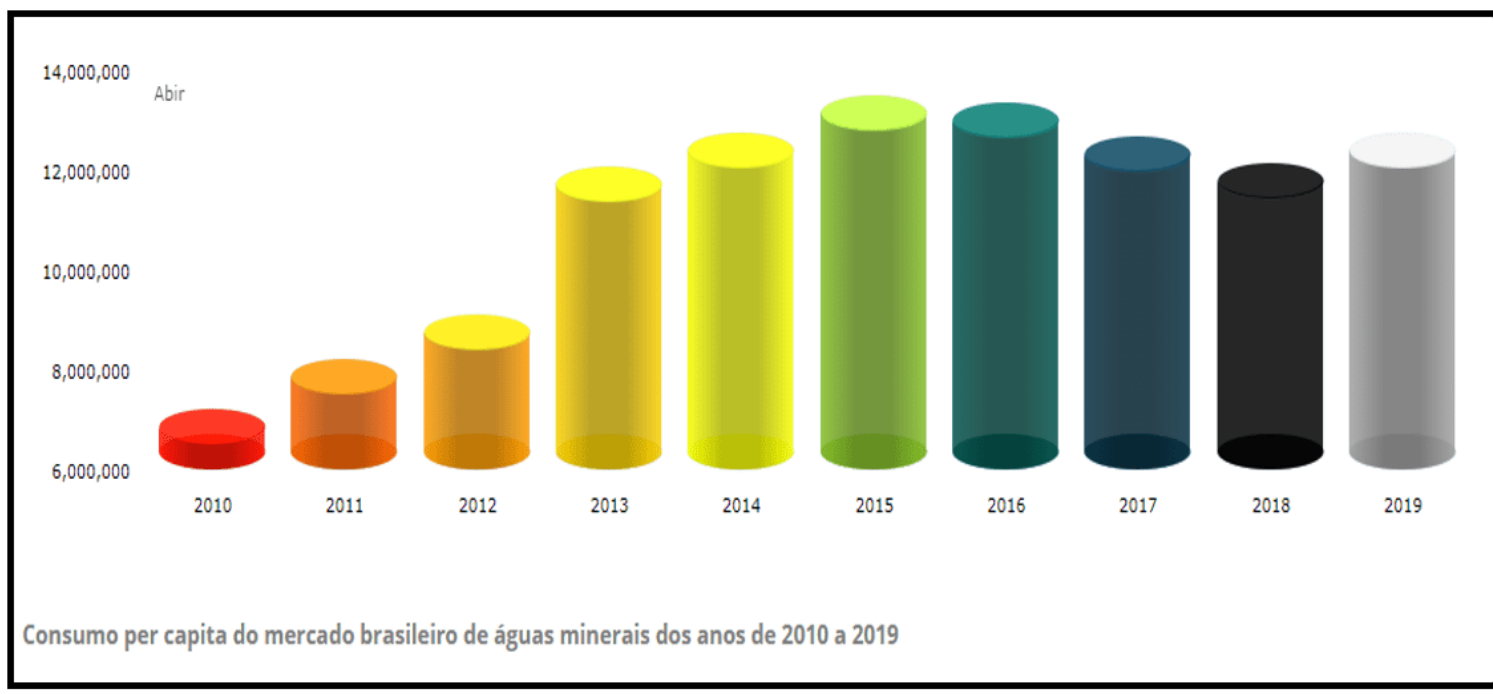

Source: Brazilian Association of Soft Drink and Non-Alcoholic Beverage Industries ABIR (2020).

In this context, the commercialization of mineral water remains in the spotlight and has a larger market than other categories of bottled products such as various beverages.

The National Mining Agency - ANM replaced the defunct National Department of Mineral Production - DNPM, in the management and planning of mineral exploration and in the exercise of the activities of companies that exploit mineral waters. So the ANM has the function of regulating the interests of granting underground mines.

The Union is based on the exploitation of mineral water, a collection of royalties, through financial compensation - CFEM - Financial Compensation for the Exploitation of Mineral Resources, whose purpose is to transfer to municipalities, States and the Union. 
The Geological Service of Brazil - CPRM (2021), a public company, linked to the Ministry of Mines and Energy, has as its attribution the development of simple on-site study that comprises sample collections, physicochemical, chemical and bacteriological analyses, including the analysis of the parameters required by RDC $274 / 2005$.

Also according to the Company of Research and Mineral Resources - CPRM, the mineral waters to be classified undergo analysis of samples in loco and laboratory both chemical components and to characterize the physicochemical properties inherent to the sources. The analyses are required and evaluated by the National Mining Agency - ANM, in compliance with the current code, chapter $X$, art. 38, and carried out by the Mineral Analysis Laboratories - LAMIN of the Geological Service of Brazil - CPRM, every three years.

Water is regulated by Brazilian states, especially those of underground origin, which for capture requires a grant instrument, according to relevant state legislation. Of the same origin, underground, mineral water is classified as ore and is submitted to the National Mining Agency - ANM[3], therefore regulated by specific legislation - Mineral Water Code - Decree-Law No. 7,841/1945.

According to Portugal Júnior; Reydon and Portugal (2015, p. 1):

\begin{abstract}
Segundo o Código de Mineração, a lavra de água mineral somente deve ser requerida por pessoa jurídica, sendo necessário o requerimento inicial de pesquisa por meio de um projeto cuja área máxima é de 50 ha. $\mathrm{O}$ alvará de pesquisa terá dois anos de prazo a partir de sua publicação, podendo ser prorrogado por igual período até mais de uma vez, tendo a possibilidade de ser cedido e/ou transferido e, também, renunciado. Após o prazo de pesquisa deve-se apresentar um Relatório Final de Pesquisa.
\end{abstract}

The requirements for the mining of mineral water are necessary and it is through its compliance and other procedures related to the Mining Concession regimes provided for in the mining legislation that the Union maintains the control and promotion of current environmental and operational water quality guidelines. Thus, in order to obtain mineral water, it is necessary to carry out prospecting research in the search for mineral water mines, based on Exploration Authorization and Mining Concession 
Regimes, in accordance with the guidelines of the Mining Code, as well as the Mineral Water Code (ANM, 2020).

Figure 2: Research and prospecting of mineral water with opening of wells.
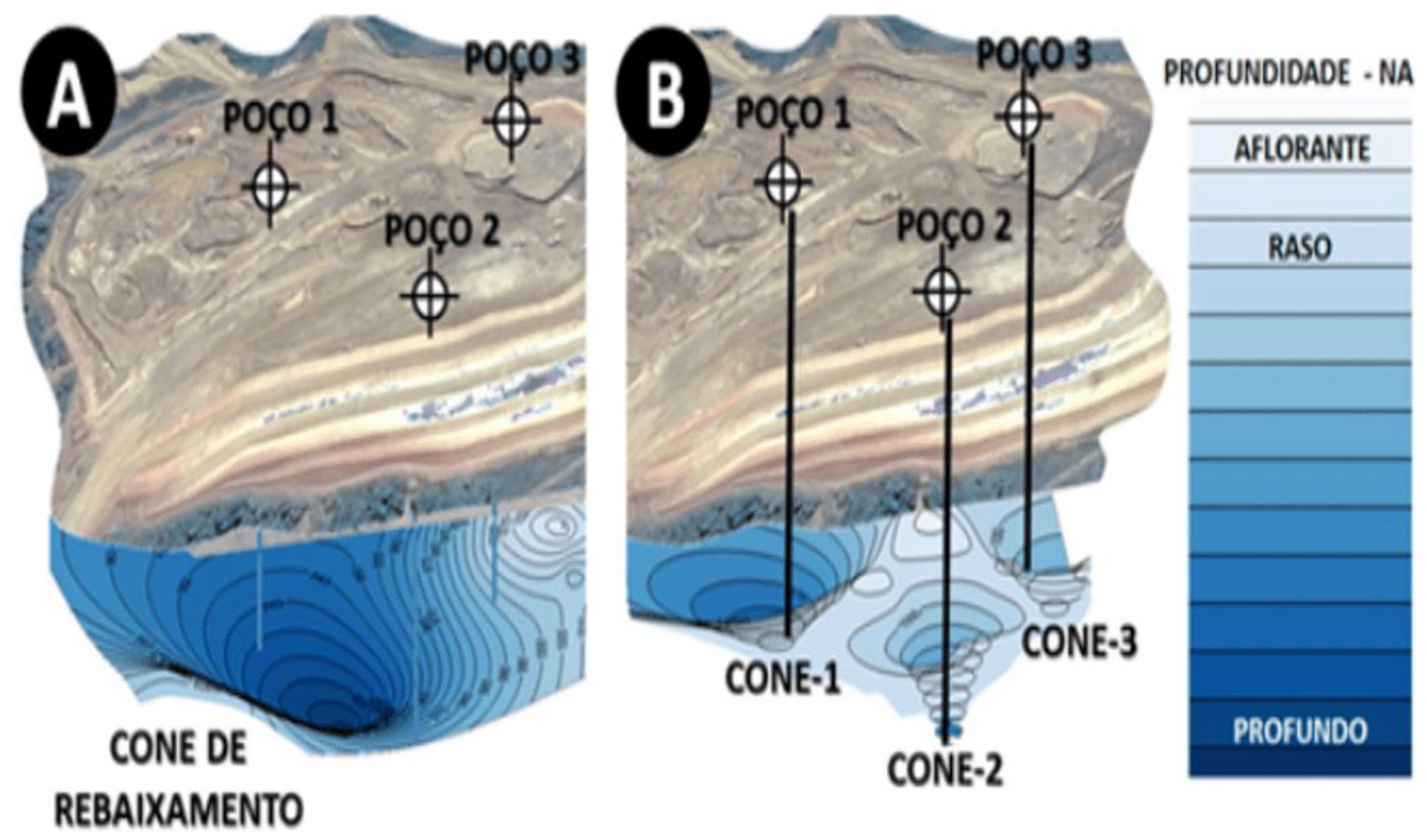

Fonte: Instituto Minere (2020).

According to Silva (2010), hydrogeological research has gained prominence in the Brazilian market, which represents the realization and prospecting of mineral, mining or decommissioning of mines. This type of research implies opening wells for the exploration of mineral waters.

According to Silva $(2010$, p. 1):

Tal pesquisa engloba uma série de estudos, que envolvem desde a geologia básica dos terrenos até informações e dados mais complexos, como geologia estrutural e geoquímica. Em se tratando dos aspectos físicos das águas subterrâneas, principalmente o sentido e a direção do fluxo hídrico subterrâneo preferencial, leva-se muito em consideração a questão estrutural do terreno (dobras, falhas, fraturas etc.).

In mine prospecting it is important to precisely define the flow of water for well allocation purposes, starting directly from the target center to obtain a better result. 
Mineral water is important in human life. Increasingly consumed in modern life, companies have been able to obtain the technical conditions for water collection to fill and maintain a management of the areas of sources, especially because it is an ore expressly consumed and easily contaminated, and requires specific monitoring of health regulatory agencies (ANM, 2020).

The authors consider that there is no conflict between the rules of the Union and the States, considering that not all groundwater is mineral and, therefore, must meet the requirements of the Mineral Water Code (ANM, 2020), which ensures the competence and legitimacy of granting the right of use to the Union.

According to Portugal Júnior; Reydon and Portugal (2015, p. 1):

A partir de uma nova institucionalidade, concebida dentro de uma abordagem sistêmica dos recursos hídricos no âmbito da bacia hidrográfica à qual pertencem as águas minerais em cada caso, os agentes econômicos deverão apresentar percepções e adotar compromissos e ações que primem por uma exploração sustentável desse recurso, considerando os limites impostos pela capacidade de renovação dada pelas condições dos ciclos hidrogeológicos e os objetivos mais amplos de preservação dessas fontes como reservas hídricas para o futuro. É dentro desse contexto maior que se devem incluir as necessárias análises e considerações com relação ao ciclo de vida, às ações voltadas ao correto destino dos resíduos gerados na produção, na comercialização e no consumo.

Mineral water exploration is irregularly distributed in the geography of the territory and many of these water deposits are found in several Brazilian states. Active mineral water mining concessions are a total of 1,236, distributed in Brazil (ASSIRATI, 2018).

The Resolution of the Collegiate Board - RDC 274/2005, addresses sanitary requirements for natural mineral water that meets a specific technical regulation, in order to ensure the maintenance of natural characteristics when it is commercialized. Thus, the control guidelines applied by ANVISA represent a guarantee of offering a quality product to the consumer, requiring mineral water exploration companies, good manufacturing practices - GMP, to ensure that mineral water is in perfect consumer condition (ANVISA). 
Resolution 275/2005 of the National Health Surveillance Agency - ANVISA, linked to the Ministry of Health, also brings the need to analyze the microbiological conditions of commercialized mineral water, the guidelines determine the need for tests from laboratory analyses with indicative samples[4] and representative samples[5] of the product.

Table 1 - Microbiological characteristics for Natural Mineral Water and Natural Water.

\begin{tabular}{|c|c|c|c|c|c|}
\hline \multirow[t]{2}{*}{ Microorganism } & \multirow[t]{2}{*}{ Indicative sample limits } & \multicolumn{4}{|c|}{ Representative sample } \\
\hline & & $\mathrm{n}$ & C & $\mathrm{m}$ & M \\
\hline $\begin{array}{l}\text { Escherichia coli } \begin{array}{r}\text { or } \\
\text { coliforme } \\
\text { (fecal) }\end{array} \\
\text { thermotolerant, at } 100 \mathrm{~mL}\end{array}$ & absence & 5 & 0 &.-- & absence \\
\hline Total coliforms, at $100 \mathrm{~mL}$ & $\begin{array}{l}<1,0 \text { UFC; }<1,1 \text { NMP or } \\
\text { absence }\end{array}$ & 5 & 1 & $\begin{array}{l}<1,0 \\
\text { UFC; } \\
<1,1 \\
\text { NMP or } \\
\text { absence }\end{array}$ & $\begin{array}{l}2.0 \text { UFC } \\
\text { or } 2.2 \\
\text { NMP }\end{array}$ \\
\hline Enterococos, at $100 \mathrm{~mL}$ & $\begin{array}{l}<1,0 \text { UFC; }<1,1 \text { NMP or } \\
\text { absence }\end{array}$ & 5 & 1 & $\begin{array}{l}<1,0 \\
\text { UFC; } \\
<1,1 \\
\text { NMP or } \\
\text { absence }\end{array}$ & $\begin{array}{l}2.0 \text { UFC } \\
\text { or } 2.2 \\
\text { NMP }\end{array}$ \\
\hline $\begin{array}{l}\text { Pseudomonas aeruginosa, } \\
\text { at } 100 \mathrm{~mL}\end{array}$ & $\begin{array}{l}<1,0 \text { UFC; }<1,1 \mathrm{NMP} \text { or } \\
\text { absence }\end{array}$ & 5 & 1 & $\begin{array}{l}<1,0 \\
\text { UFC; } \\
<1,1 \\
\text { NMP or } \\
\text { absence }\end{array}$ & $\begin{array}{l}2.0 \text { UFC } \\
\text { or } 2.2 \\
\text { NMP }\end{array}$ \\
\hline $\begin{array}{l}\text { Sulphite } \\
\text { clostridia or Clostridium } \\
\text { perfringens, at } 100 \mathrm{~mL}\end{array}$ & $\begin{array}{l}<1,0 \text { UFC; }<1,1 \text { NMP or } \\
\text { absence }\end{array}$ & 5 & 1 & $\begin{array}{l}<1,0 \\
\text { UFC; } \\
<1,1 \\
\text { NMP or }\end{array}$ & $\begin{array}{l}2.0 \text { UFC } \\
\text { or } 2.2 \\
\text { NMP }\end{array}$ \\
\hline
\end{tabular}




\section{absence}

Source: ANVISA (2005).

Companies wishing to act in the market must properly carry out all the guidelines of sanitary legislation to ensure healthy consumption, presenting a water collection project that must go through various normative procedures (from the Research Application, Positive Research Final Report and Mining Requirement (CAETANO; PEREIRA, DOURADO, 2012).

The Union shall determine through the Water Code groundwater protection measures when it comes to marketing, and the responsibility for maintaining the quality of mineral waters is imposed.

In the last decade, new instruments for analyzing the quality and presence of contaminants have ensured the protection of human consumption waters (ESTEVES, 2012).

In relation to the activity of mining, the parameter is operations that are ordered with the objective of industrial exploitation of the mining environment, inserted processes of extraction of mineral substances, for this reason all private agents must obtain the concession and in relation to mineral water will represent the phase during the execution of the use without environmental compromise of the characteristics of the mineral water extraction environment (COELHO; DUARTE, 2003).

In this respect, the ANM is the body that has the competence to determine mechanisms of regulation, granting and supervision, in relation to plans for exploration and use of mineral resources, including the removal of mineral water from the soil or subsoil, throughout the national territory. Therefore, the ANM has the mission to manage and control all activities involving mineral exploration.

The Mineral Water Code - CAM (Decree-Law No. 7,841/1945) determines the competence of the ANM, which is currently the representative of the obligations and rights that previously belonged to the now defunct National Department of Mineral 
Production - DNPM, in accordance with Law No. 13,575/2017, the process of supervising the exploitation of mineral and potable waters for table use in all its aspects must result in accordance with Art. 9 and 23:

Art. 9. Por lavra de uma fonte de água mineral, termal, gasosa, potável de mesa ou destinada a fins balneários, entendem-se todos os trabalhos e atividades de captação, condução, distribuição e aproveitamento das águas. (...)

Art. 23. A fiscalização da exploração, em todos os seus aspectos, de águas minerais, termais, gasosas e potáveis de mesa, engarrafadas ou destinadas a fins balneários, será exercida pela Agência Nacional de Mineração - ANM.

Art. 24. As autoridades sanitárias e administrativas federais, estaduais e municipais, deverão auxiliar e assistir a ANM em tudo que for necessário ao fiel cumprimento desta lei (BRASIL, 2017, p. 1).

The creation of the National Mining Agency was the new mining framework, and only then were provisional measures no. 789, 790 and 791 of 2017 instituted, which focused on following the constitutional guidelines. This new moment of reassessment and improvement of the legal framework of mining, defines in terms of legislative policies, the competence over the regulation of groundwater under the management of the National Water Agency - ANA, while mineral waters, because they are considered mineral, are managed by the National Mining Agency - ANM (ANM, 2020).

In the Minas Code of 1934, the union's right of private guardianship was determined, therefore, they became the responsibility of the federal sphere, leaving the state management. Only from Decree 78.171/1976, health agencies began to develop a higher level of control in terms of analyses of mineral water quality (SERRA, 2009).

Based on Decree 78.171/1976, several other regulations were created through ordinances of the Ministers of Mines and Energy and Health, with the objective of determining regulatory measures of the sector that generated greater control over mineral water quality standards (SERRA, 2009).

After the creation of new measures, conflicts began to emerge between the ANM bodies and the Health Secretariats, the results constituted measures of supervision 
and legal regulation that brought differences that generated conflicts of competence with the health agencies.

According to Caetano, Pereira and Dourado (2012, p. 3):

O controle sanitário da qualidade das águas minerais destinada ao consumo humano, bem como a fiscalização sanitária dos locais e equipamentos relacionados com a comercialização do produto são competências do Ministério da Saúde das Secretarias de Saúde dos Estados e Distrito Federal pelo Decreto no 78.171/1976 (BRASIL, 1976). No entanto, existe um procedimento ainda atuante pelos empresários da indústria de água mineral de atendimento ao Decreto-lei ㄲo 4.147/1942. A Portaria 222/1997 do DNPM apresentou conflito com a Portaria 326/1997 do Ministério da Saúde (BRASIL, 1997), pois ambos estabelecem procedimentos para as condições higiênicosanitárias e exames ambulatoriais e laboratoriais dos funcionários, sendo que essa última é mais detalhada.

With Resolution 21/20 published by the ANM, there was a change that had as dynamic the alteration of the internal rules, bringing in this context, the detailing of attributions for cases of mediation and conciliation, with the purpose of ending the conflicts of functions. These guidelines were determined in Article 2, XIV, of Law 13,474/2017, in order to establish territorial conflicts between groundwater in the States managed by ANA and mineral waters administered by ANM and other mining rights (ANM, 2020).

Serra (2009) evaluates that water is a primordial resource for life on earth. The quality of water for human consumption represents a factor of the greatest relevance, since quality water promotes health.

Mineral water must meet potability standards according to Anvisa regulations, since, not being perfectly served, it can become a vehicle for the transmission of diseases through infectious agents. Considering that water is a food and intake present in the daily life of every human being, a poor quality water available can bring great harm to a community (SERRA, 2009).

Esteves (2012, p. 25) analyzes that:

A água é necessária à vida e todas as manifestações de vida devem ser compreendidas como recíprocas, nada podendo ser analisado senão dentro de uma visão holística deste todo complexo que é a realidade. O conjunto de 
normas jurídicas que visa disciplinar a água mineral é um elemento da organização social e não um conjunto estático de normas em aplicação da doutrina puramente positivista.

In this context, all chemical elements present in water should have the appropriate concentrations and quality represented by the absence of contaminants that can cause diseases such as worminosis, typhoid fever, cholera and other infectious diseases.

There is care for health and water protection and management agencies to avoid contamination of groundwater, destined to the consumption of the population, incorporating a socio-environmental responsibility for water management in the state sphere (SERRA, 2009).

Water being considered as a mineral, constitutes a federal management that demonstrates different policies and criteria that generate conflicts of complex resolutions in relation to municipal, state and federal managements, to the extent that they are economic interests of companies and consumers, as well as representatives who need to make decisions (VAITSMAN; VAITSMAN, 2015).

\section{THE BENEFITS OF MINERAL WATER FOR HEALTH}

The process to make groundwater an available resource to be industrialized, requires stages of research, mining and laboratory treatments in determining the capacity of quantitative care to the industry, as well as the conditions of asepsis and microbiological control to ensure quality to human consumption, a necessary and important condition as a vector of health promotion (ANM, 2020).

Mineral water benefits the body and its organs, especially the renal system, which has the function of filtering and harnessing important elements, eliminating what the body does not absorb, from the urinary system. Thus, when water transports nutrients, it also has the function of maintaining a thermoregulation process, which represents stability of body temperature levels (VAISTMAN; VAISTMAN, 2015).

Mineral water brings great therapeutic advantages in that it has essential nutrients to the body's health, such as minerals, calcium, fluoride and magnesium without being 
subjected to chemical process, therefore, because it is pure, it does not require any human intervention in its composition. In this respect, there are great differences between ingesting mineral water and treated water, considering that natural mineral water has been recognized as medicinal for assisting in the proper functioning of the body's systems (VAISTMAN; VAISTMAN, 2015).

In functional terms it is essential to make possible the control of hormones, the due oxygenation of the blood and the expulsion of harmful toxins from the body. At all ages the human being lives better when consuming at least one liter of water per day, to keep the body hydrated, although the World Health Organization - WHO recommends a daily intake of two liters of water per day. For the Brazilian Society of Nutrition Food - SBAN, the amount of water needed for the proper functioning of the organism is variable, considering that it can be affected by climate, clothing, physical activities or other factors, so that the daily recommendation for ingestion varies by age group, from 07 to 12 months to more than 70 years, including pregnant and lactating women, with consumption ranging from 0.8 to $3.8 \mathrm{l} / \mathrm{day}$ (IOM, 2006; SBAN, 2016).

In relation to people over 60 years, there is a loss of the ability to thermoregulate body temperature, represented by the feeling of seed, heat or cold. Therefore, in this age group, people are more prone to dehydration. According to the Brazilian Society of Nutrition Nutrition - SBAN, water needs in the elderly are no different from those for young adults. However, there are a number of conditions, both physiological and morbid, that alter the water balance in this specific population, putting them at greater risk in relation to dehydration states (SBAN, 2016). 
Figure 3: Care against dehydration.
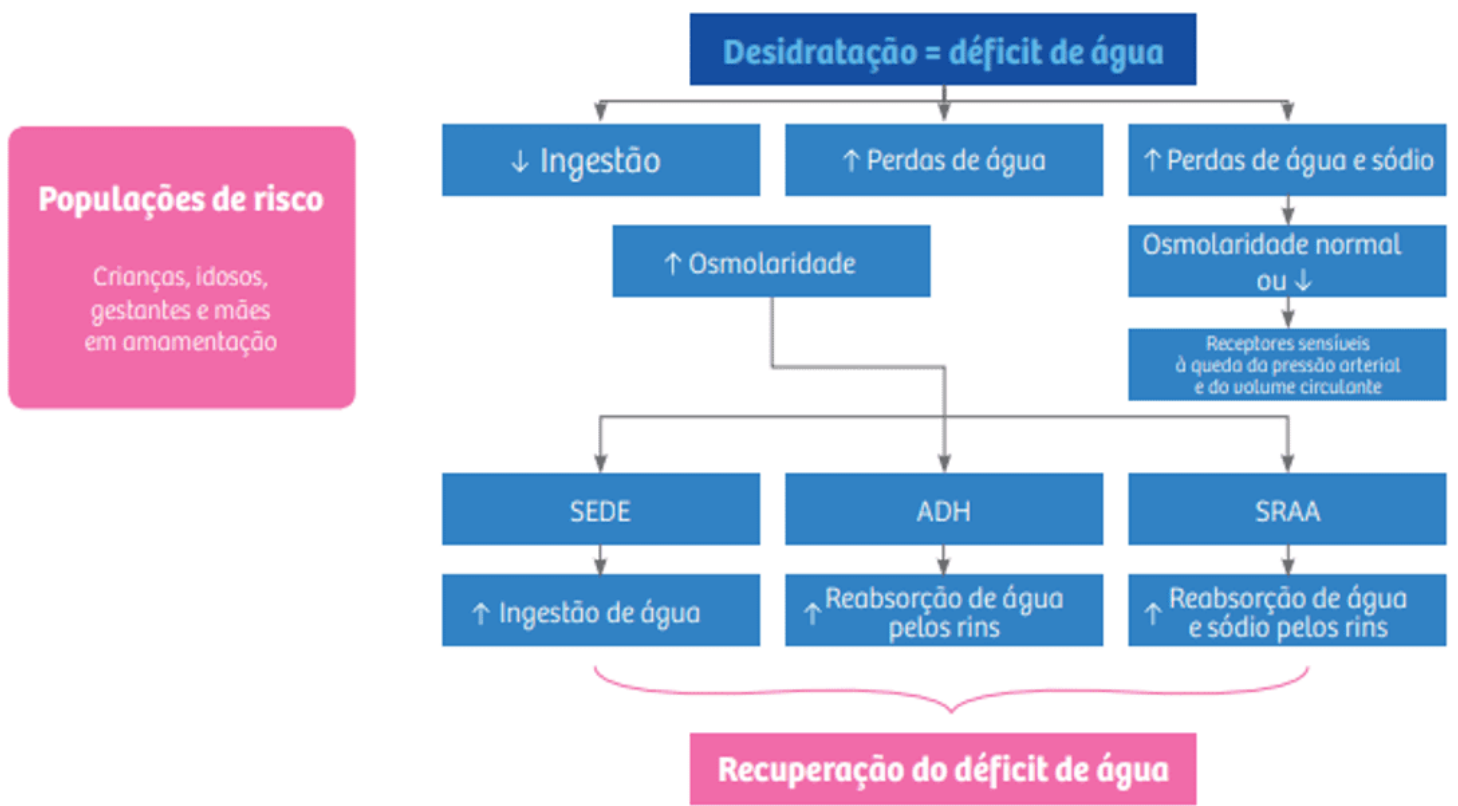

Source: Azevedo; Pereira and Paiva (2019).

Dehydration care should also be part of the lives of children and pregnant women, who must maintain satisfactory intake of mineral water in order to keep diuretic function balanced. As mineral water has drug and therapeutic properties in its composition determined by the type of rock it passes through, by the time of permanence and temperature of the aquifer, they can present several compositions, with predominance of certain characteristic chemical elements, such as mineral waters with a higher predominance of ferruginous elements, which has therapeutic indication for anemia problems, allergies and treatment of parasites. On the other hand, alkaline-bicarbonate mineral water has the function of improving gastric, hepatic and pancreatic functioning (KUHNE, 2010).

Sulfurous mineral water, with predominance of the sulfur element, has helped people with rheumatic problems and other varieties of infections and dermatitis. There are still mineral waters that have radioactive elements in their composition, also important in therapeutic activities, especially in treatments in patients with oral problems, enabling the improvement of digestive functioning. 
Magnesian mineral waters have a laxative function and, therefore, regulate the intestine and the functioning of the stomach, those with carbonic properties have moisturizing functions for the skin. lodized waters have therapeutic functions in organic inflammatory situations, insufficiency of the thyroid gland, and rheumatism, liver and kidney problems. Litinated mineral waters, on the other hand, are of great importance in the uric acid purification process and have a calming function (KUHNE, 2010).

Calcium-rich mineral waters have great therapeutic properties for bone strengthening, osteoporosis disease and improvement of muscle conditions, and those with a high potassium concentration are able to maintain central nervous system toning (KUHNE, 2010).

The great health benefit of mineral water consumption is unquestionable, considering its effectiveness in contributing to nutrition and health of the organism.

According to Azevedo; Pereira and Paiva (2019, p. 11):

A água pode contribuir para a ingestão de alguns micronutrientes, entretanto, no Brasil, grande parte das águas minerais engarrafadas ou de torneira não são consideradas fontes importantes para esses minerais. A classificação europeia das águas minerais descreve que águas ricas em sódio contém $>200$ $\mathrm{mg} / \mathrm{L}$, em cálcio > $150 \mathrm{mg} / \mathrm{L}$, em bicarbonato $>600 \mathrm{mg} / \mathrm{L}$, em magnésio $>50$ $\mathrm{mg} / \mathrm{L}$ e flúor $>1 \mathrm{mg} / \mathrm{L}$. Não há referências para o potássio, pois em geral não é representativo nas águas.

Mineral waters are rich in minerals, salts and elements that strengthen the body. The European classification of mineral waters demonstrates the levels of presence of micronutrients important for health promotion.

The human body to be healthy must remain hydrated, considering that the urinary system of which the kidneys are part, have about $83 \%$ of water, as well as the cardiovascular system, lungs and blood system, has around $80 \%$. Therefore, the body needs to be perfectly hydrated to maintain digestive functions and cell nutrition, in addition to the importance of water in the lubrication function of vision and bone system, functioning of the nervous system and balance of body temperature (KUHNE, 2010). 
According to Azevedo; Pereira and Paiva (2019, p. 8):

As necessidades de água nos idosos não são diferentes daquelas para os adultos jovens. Entretanto, existe uma série de condições, tanto fisiológicas quanto mórbidas, que alteram o balanço hídrico nesta população específica, colocando-os sob maior risco em relação a estados de desidratação. As crianças apresentam diferenças fisiológicas importantes em comparação aos adultos, como sua maior área de superfície em relação a massa corpórea, a menor habilidade para produzir suor e um maior metabolismo da água.

In this respect, the human body depending on the activities performed, age, height and body weight, require a higher or lower water intake. Considering the above variables, human water intake should be sufficient to replenish the body's needs.

\section{FINAL CONSIDERATIONS}

The present work had as a guide question: What is the importance of mineral water quality for human consumption and health promotion? It is possible to conclude that to ensure the quality of water for human consumption and quality of life, compliance with regulatory legislation and technical monitoring in the industry from the packaging and microbiological control, enable guarantee of the final quality of mineral water, to be made available in the commercial use of mineral water sources as safe food for human consumption.

These aspects related to mineral water mining, for the quality of human consumption and health promotion, showed that the guidelines since research, mining and processing, that is, industrialization, from 1976, began to have a stricter control of water quality through the agencies responsible for ensuring protection to the health of consumers.

It was evidenced that mineral water brings great health benefits, where the different levels of existing nutrients help in the most diverse health problems, to the extent that its drug properties are recommended in treatments of various diseases that affect human health.Due to the presence of a wide variety of mineral salts and natural chemical elements in the composition of mineral waters, these present beneficial characteristics in disease treatments, considering the prevalence of each type of 
mineral water, which characterize it in: ferruginous, alkaline-bicarbonate, sulfurous, radioactive, magnesian and iodized, can aid in therapeutic activities in medicinal treatments in patients.

In terms of public health, there are several problems in the body that can be treated with mineral waters rich in prevalent elements that give specific characteristics to waters, where these therapeutic properties provide health benefits from regular consumption of mineral water, as well as other uses such as balneotherapy, etc.

The legislative guidelines comply with the guidelines of the Mining Code and Water Code and with the new resolutions of 2017, which instituted the National Mining Agency - ANM and the extinction of the National Department of Mineral Production DNPM, have become an efficient and speedy mechanism in solving mining problems.

Mineral waters are controlled by the federal administration, through the ANM in the monitoring of mineral water extraction activities. The current guidelines facilitated the processing of the mine exploration process, providing the increase of production and consumption of mineral water by the population, through the confidence of the efficient control of the quality of available water, through compliance with the regulations of Anvisa and anm legislation.

\section{REFERENCES}

ABIR - Associação Brasileira das Indústrias de Refrigerante e de Bebidas Não Alcoólicas. Águas minerais. 2020. Disponível em: <https://abir.org.br/osetor/dados/aguas-minerais/>. Acesso em: 18 abr. 2021.

ANM - Agência Nacional de Mineração. Sumário Mineral. DALLA COSTA, Marina Marques; MEDEIROS, Karina Andrade; LIMA, Thiers Muniz (Coord.). Brasília: ANM, 2019.

ANM - Agência Nacional de Mineração. 05/2018. Processos Minerários (Água Mineral). Sistema de Informações Geográficas da Mineração (SIGMINE). 
ANVISA - Agência Nacional de Vigilância Sanitária. Ministério da Saúde. Resolução - RDC no 275 de 22 de Setembro de 2005 . Disponível em: http://bvsms.saude.gov.br/bvs/saudelegis/anvisa/2005/rdc0275_22_09_2005.ht ml\#: :text=A\%20\%C3\%81gua\%20Mineral\%20Natural\%20e,Mineral\%20Natural\%20 e\%20\%C3\%81gua\%20Natural. Acesso em: 23 abr. 2021.

BRASIL. Lei no 13.575, de 26 de Dezembro de 2017. Disponível em: <www.planalto.gov.br/ccivil_03/_ato2015-2018/2017/lei/13575.htm>. Acesso em: 04 abr. 2021.

CAETANO, Lúcio Carramilho; PEREIRA, Sueli Yoshinaga; DOURADO, Francisco. Os conflitos do gerenciamento da água mineral no Brasil: Estudo de caso no Estado do Rio de Janeiro. Revista Holos Environment, v. 12, n. 2, pp. 132, 2012.

COELHO, Virgília M. T; DUARTE, Uriel. Perímetros de proteção para fontes naturais de águas minerais. Revista Águas Subterrâneas, n. 17, maio 2003.

CPRM - Companhia de Pesquisa e Recursos Minerais. Águas minerais. 2020. Disponível em: <https://aguamineral.cprm.gov.br/geo_meio_ambiente.html>. Acesso em: 18 dez. 2021.

DNPM - Departamento Nacional da Produção Mineral. 2015. O passo a passo para explorar água mineral. DNPM (última modificação 24/3/2015). Disponível em: <http://www.anm.gov.br/assuntos/aopublico/paginas/explorar-agua-mineral-vejacomo-e-facil>. Acesso em: 14 dez. 2021.

ESTEVES, Cristina Campos. Regime jurídico das águas minerais na Constituição de 1988. 2012. 274 f. Tese (Doutorado em Geociências) - Universidade Estadual de Campinas - UNICAMP, Campinas, SP, 2012.

FEITOSA, Fernando A. C. Hidrogeologia: conceitos e aplicações / organização e coordenação científica / Fernando A. C. Feitosa... (et. al.) ... 3. ed. rev. amp. - Rio de Janeiro : CPRM ; LABHID, 2008. 812 p. 
GORINI, Ana Paula Fontenelle. Mercado de água (envasada) no Brasil e no mundo. Rio de Janeiro: BNDES Setorial, 2000.

INSTITUTO Minere. Águas subterrâneas. Disponível em: <https://institutominere.com.br/blog/misteriosos-caminhos-das-aguas-subterraneas>. Acesso em: 03 abr. 2021.

KARMANN, I. 2001. Ciclo da Água, Água Subterrânea e sua Ação Geológica. In: Teixeira W, Toledo M.G.M, Fairchild T.R., Taioli F. (orgs.). Decifrando a Terra. São Paulo, Oficina de Textos, $1^{\text {a }}$ ed, 568p. ISBN: 9788504014396

KUHNE, Louis. Cura pela água. 1. ed. São Paulo: Hemus, 2010.

Pitaluga, C. M. Fatores que Influenciam o Consumo de Água Mineral. Disponível em: https://repositorio.ufms.br/handle/123456789/863. Acesso em: 17 dez. 2021.

PORTUGAL JÚNIOR, Pedro dos Santos; REYDON, Bastiaan Philip; PORTUGAL, Nilton dos Santos. As águas minerais no Brasil: Uma análise do mercado e da institucionalidade para uma gestão integrada e sustentável. Revista Ambiente \& Água On Line, v. 10, n. 2, Taubaté/SP, jun. 2015.

SBAN - Sociedade Brasileira de Alimentação e Nutrição. 2016. Água, Hidratação e Saúde. Disponível em: http://www.sban.org.br/documentos-tecnicosinterno.aspx?post=2. Acesso em: 20 dez. 2021.

SERRA, Sílvia Helena. Águas minerais do Brasil. 1. ed. São Paulo: Millenium, 2009.

SILVA, Marcus Vinícius Andrade. Os misteriosos caminhos das águas subterrâneas. 2010. Disponível em: <https://institutominere.com.br/blog/misteriososcaminhos-das-aguas-subterraneas>. Acesso em: 18 de mai. de 2021.

VAITSMAN, Delmo Santiago; VAITSMAN, Mauro Santiago. Água mineral. 3. ed. São Paulo: Interciência, 2015. 


\section{APPENDIX - REFERENCE FOOTNOTE}

2. The National Mining Agency was created on July 25, 2017, through Provisional Measure No. 791. With a source headquarters in Brasilia, the agency is directly related to the Ministry of Mines and Energy, and has patrimonial and administrative autonomy.

3. The National Mining Agency was created on July 25, 2017, through Provisional Measure No. 791. With a source headquarters in Brasilia, the agency is directly related to the Ministry of Mines and Energy, and has patrimonial and administrative autonomy.

4. The sample indicated represents Indicative sample the sample that is condemned when the presence of Escherichia coli or thermotolerant coliforms (fecal) is found or when the number of total coliforms and or enterococos and or Pseudomonas aeruginosa and or sulphite chlorestides or Clostridium perfringens is greater than the limit established for indicative sample (RESOLUTION 275/2005 - ANVISA).

5. The representative sample is mandatory in compliance with the legal provisions in force. Except for activities that require sampling for investigation (related to suspicion or identification of problems at departure, for confirmation or verification of their nature and extent or for information on possible sources of problem) or that require strict inspections (statistical plans with greater power of discrimination of failures) as specified in Resolution275/2005 - ANVISA.

Submitted: October, 2021.

Approved: December, 2021. 